\title{
ARTISTIC AND CONCEPTUAL ANALYSIS OF THE FICTION WORK OF ANGARAY
}

Muhammad Sajid Khan*

\begin{abstract}
Reading habits among young generation is going to declining and culture of reading books is modified to modern methods of communication like browsing social sites and internet, playing on cell phones and watching T.V. This era modernization has taken away the youth from reading habits. It is important that the young generation learns about the rich Urdu literature including Urdu fiction in which several writers have significantly contributed. The emergence of Urdu literature facilitated the expansion of Urdu language. Fiction writers try to indicate important weaknesses of the society, cultural traditions, and norms, so as to find out the solutions to these issues. There were so many fictional works in Urdu literature having done during the progressive and independent movement. "ANGARAY" is a collection of fictional short stories authored by four young writers who had a progressive approach and tried in their own way to bring forth several social issues through their work at the time British India. This paper attempts to present a brief history of this collection and the consequences emerging out of its publication at that time. The study is reviewed and analyzed the criticism on selected short stories of subsequent publication. The study found that the readers would find the ideas and views of the four writers in the present time may provide them some relief from the opposition they faced on publication of their work.
\end{abstract}

Keywords: Urdu fiction, social beliefs, social traditions

\section{Introduction}

Urdu literature historically associated with the growth of Urdu language. "Urdu" is the Turkish word which means military camp and has its meaning in Urdu is "Lashkar". It has borrowed the words from Persian and written in Arabic alphabet styles. ${ }^{1}$ Urdu is the language widely spoken in Pakistan and India and regarded as a wide cultural heritage of Muslims. In British India Urdu was used as Muslim identity and play a vital role in making political unity of Muslims. It became the print language for newly emerging nation and purely reflects the ideas of independence and socio-economic change while it became a trend to in $20^{\text {th }}$ centuries. $^{2}$

The short story is the most significant type of Urdu writing. This type of writing made its situation in twentieth century and got an incredible fame in a brief span. Preceding it the convention of novel and dastan was available in Urdu writing. Against the perfect air of dastan, an accurate sort of view is kept in novel. In Urdu this type of writing has gone

\footnotetext{
* Muhammad Sajid Khan, Ph.D. Assistant Professor, Department of Urdu, University of Karachi

${ }^{1}$ Kausar, Robina, Sarwar, Muhammad \& Shabbir, Muhammad. "The Past and Present Trends of the Urdu Literature Collectively with Its Derivation and Geographic Circulation". American Journal of Social Science Research Vol. 1, No. 3, (2015): 136-140

${ }^{2}$ Omar, Q. Twentieth-Century Urdu Literature. Published in Handbook of Twentieth-Century Literatures of India, ed. by Nalini Natarajan, (Westport, CT: Greenwood Press, 1996)
} 
under the western impacts. In addition, the predominant conditions likewise requested that the authenticity of novel must be embraced. Because of unfavorable political conditions the India was in a state defenselessness. More over from the social perspective the general population here were under the abuse. Poverty and social exploitation were normal. The general population was running from the substances of life. It was the need of time that they should be conversed with face the substances and the certainties. The shades of hatred which had established to put down and suppressed the general public should be presented and transformed. For social improvement the novel could have been utilized, which has a capacity to describe the public activity in a superior manner. This structure had made its place effectively in the west. In India because of specific conditions western information had come to the region. In view of this the scholars here had familiar with the type of novel, and again discovering this structure great to the neighborhood conditions, incorporated into Urdu writing. The epic writing technique came in Urdu writing from English writing. In spite of old stories genuine was made the point in them. Rather than otherworldly components the characters and occasions from the genuine were incorporated into it. The novel of Deputy Nazir Ahmed "Mirrat ul Uroos" is viewed as the main Urdu tale which was written in 1869. At that point Rattan Nath Sarshar, Munshi Sajjad, Abdul Haleem Sharar, and Munshi Prem Chand's novel were composed. The English colonial rule and prevalence of English language gave an opportunity to the educated people of India to be advantageous by the western language and writing and adapt the regional writing with the cutting edge thoughts and belief system. In this way, accomplishing direction from the western writing new style was obtained. ${ }^{3}$

Fiction is an important part of any literature. In the Sub-Continent of India-Pakistan, except the recent two decades, there was much want of literature as there were a good number of readers and literature-lovers. Urdu fiction has its roots of the different modern school of thoughts such as Marxism, Expressionism, Psychoanalysis, Existentialism, and Impressionism. Translation of many European stories in Urdu introduced short story writing in Urdu Literature. Translations in the Urdu Language have flourished the short stories in Urdu literature. ${ }^{4}$ Modernization approach in Urdu literature came out in the writings of $18^{\text {th }}$ and 19th Century. Shibli and Hali primarily related their writings to the society. Then as time passed these writings are divided into different movements of Independence movement, progressive movement and cultural movement which has great impact on social reforms. ${ }^{5}$

Urdu fiction has raised many social issues for several decades in the recent history of Pakistan and India. A few fiction writers dared to reflect some important social issues in a bold manner. This manner among many literary circles was labeled as obscene or at least unfit for the standard literature. The book ' $A N G A R A Y$ ' is the theme of this paper. This collection of fiction stories was much criticized by many critics during the early days of its publication. In present days, some writers appear appreciating the boldness of the young writers of this book. Many female and male writers wrote short stories on

\footnotetext{
${ }^{3}$ Abbas et al., Urdu Short Story: Technique and History Journal of Applied Environmental and Biological Sciences, 6(11)148-153, (2016)

${ }^{4}$ Kausar, Op.cit.

${ }^{5}$ A.Waqar. Besween Sadi Ki Adabi Tehriken, Pakistani Adab: Tanqid. Ed. Rasheed Amjad \& Farooq Ali. (Rawalpindi: Federal Govt. Sir Syed College. 1982).
} 
romanticism and social criticism. Short stories in Urdu cover all socio-economic, cultural, religious and political aspects of life. The most famous stories were about issues of independence and discussed the culture of sub-continent. ${ }^{6}$

After novel which got significance was short story composing. From the earliest starting point the short story has set up its solid position in Urdu writing. Furthermore, from the earliest it has come to the statures of the standard. The most dominant look at western writing is available in Urdu short story. Also, Urdu short story found an encompassing which was extremely useful for its foundation and progression. Urdu got such story tellers who had the ability to take it in the high position. Urdu short story has a thin connection with the abstract understanding and intellectual encouragement of twentieth century. It is the articulation of another comprehension and revelation of another learning which appears the impression of the type of that story which had diverse attributes and whose advancement became known in the Europe and American nineteenth century, with respect to as Urdu, the start of short story had no sign before the compositions of Prem Chand and Syed Sajjad Haider Yaldrum. ${ }^{7}$

The 1930s was a critical decade for Indians seeing the formation of the disputable Angarey in 1932. Angarey; printed and distributed in Urdu is an accumulation of various writers inside one spread. Here, were a gathering of young writers who were completely unconventional, straightforwardly diverged of religion, social traditions and envious of social change. They were hopeful and anxious for radical change as they were against built up customs and shows. Sajjad Zaheer contributed the more prominent bit of stories to Angarey yet specific judgment was coordinated towards two of these Neend Nahin Aatae (Sleep does not come) and Jannat ki Basharat (Annuciaition of Heaven). The two stories had a sexual subject yet one summoned the possibility of God, the Quran and whores. Ahmad Ali's articles about socio-economic issues of society particularly uncovered the reality of sufferings and poverty of Muslim ladies. This was adequate ground for explaining the panics of throughout the Subcontinent. ${ }^{8}$ This publication is an example of freedom of expression at the time of colonial domination and came out to give voice to emotions of young generation. Although these short stories given the circumstances which are adequately explain the norms, values and attitudes of people which are acceptable in today's society.

\section{Methodology}

The study is based on reviews of writings about the one of the most famous collection of short stories "Angaaray" to analyze about the impact and criticism of writings. The method of the research used was analyzing the reviews and criticism on content through reviewing the previous literature about short stories. The purpose of selecting this method is interviewing people would not fulfill the objective of the study. This publication was written by Sajjad Zahir, Ahmed Ali, Rashid Jahan, and Mahmud-uzZafar and first published in 1932. They were young writers who influence by Indian independence and become the pioneer on banned on freedom of expression at Sub-

\footnotetext{
${ }^{6}$ Kausar, et.al. Op.cit.

${ }^{7}$ Hussain, P. A. Aks Aur Ainay. (Lakhnao: Idara Farogh e Urdu, 1970).

8 Ahmed, Talat. Literature and Politics in the age of Nationalism, (New Delhi: Routledge Publications,, 2009), pp.16, 181
} 
Continent. The book consists of nine stories and a play. The book was banned and all copies were set on fire. The book was republished in $1995 .{ }^{9}$

South Asia enjoys a very rich historical heritage in terms of culture. This rich has turned this soil exceptional in arts and sciences so much so that in various periods of times the foreigners have attempted to have to as their permanent place to live. For this reason, its history has been politically very eventful. Especially, the colonial period has got notable significance in the history of this region. Various characteristics of this soil are interesting while these have also given emergence to the discussion in different areas. The Urdu literature can be named as such one prominent point among these areas. The modern Urdu is an outcome of the influences of the international scenario. The thoughts of Sir Syed Ahmed Khan and the consequently emerging new literature is an example of these influences. The aggressive reaction, experienced in the Indian approach, on the realization of the need for reform, can be observed first in the controversial book 'Angaray' which was confiscated immediately after its publication. This publication proved drastic in the Urdu literary circles. Experts from various walks of life criticized this book. According to Farman Fatehpuri:

As soon as Angaray was brought out, most of the Urdu newspapers and journals published articles against it. The fiction work of this book was declared opposed to religion, and obscene, while confiscation of the book was also demanded. ${ }^{10}$

The book was written under the influence of modernism and colonial rule which did not accept the society. Despite criticism, became a revolutionary literature for young generation.

Sajjad Zaheer, Ahmed Ali, Rasheed Jahan and Mahmood ul Zafar are all these young writers were laced with western education, deep knowledge of international movements and contemporary consciousness. At the time of the publication of this collection these authors aged between 22 to 30 years. This 'sensitive' age is known as youth in terms of psychology. According to Dr. Jameel Jalibi:

This is the age when a person dreams and desires to turn his society as the truth of his dream. It is the age when he generally experiences disagreement with the traditional values, boldness, courage and the spirit to do something. These influences reflect in these stories. Rather, it seems as if these values have been targeted with a well-thought plan. ${ }^{11}$

The young writers have been considered the progressive writers and influenced by Marxist approach during their studies. The stories described in the said collection show freshness and new experiences. The reading of these stories supports the idea that such experiences bring new life and energy to cultures and civilizations. The rebellion and revolutionary approach applied in this book does not carry destructive impact but it also develops the consciousness for reconstruction.

\footnotetext{
${ }^{9}$ Angarey: Nine Stories and a Play Paperback - April 2, 2014 Access from https://www.amazon.com/Angarey-9-Stories-Play-Mahmuduzzafar/dp/8129131080

${ }_{11}^{10}$ Farman Fatehpuri, Urdu Afsana aur Afsana Nigar, (Delhi: Jamia Millia, 1982), p. 115.

11 Jameel Jalibi, Adabi Zawiye, Mashmoola Alamat, (Llahore, 1992), p.6.
} 
Some critics are of the view that the authors of the book under influence of sentiment and emotion did bear a revolutionary mind but they lacked a clear course of action as the next step. In the words of Waqar Azeem:

\begin{abstract}
Angaray is an artistic mix of a number of minor and main issues relating to the arts of the West and the life of the East. The stories of this collection present sharp images of the weird personalities and mindsets developed by the religious, social and political life of India. These images are strictly honest, showing liberal and bold approaches. The images reveal bitter satire and extreme feelings. This bitter satire appears bearing ridicule and frustration at some places while at other it shows moderation. Keeping the theme in view, it is hard to find such extensiveness, truthfulness and boldness in the Urdu fiction. Using their artistic courage the writers of Angaray has brought those aspects of life into lime-lights which were so far deliberately kept unrevealed. ${ }^{12}$
\end{abstract}

The short story was the voice of new generation and betrayal with the existing social attitudes, social pressure and social norms which suppress the individuals. The said collection of fiction is primarily a piece of literature and its authors wanted through their literary service to diagnose social evils so as to offer positive remedy and promote healthy trends. During various times a number of thinkers, philosophers, and creative persons have performed the same thing in their own styles. Maulana Altaf Hussain Hali, Akbar Allahabadi, Sir Syed Ahmed Khan and other renowned personalities made efforts to enlighten the minds through consciousness and awareness. While it would not be appropriate to expect of an international approach or joint philosophy and a concrete course of action from the authors of Angaray, there is a capacity to disagree with the view that these authors did not have a clear course of action. According to Anwer Sadeed:

No doubt Angaray tried to violate the Eastern cultural traditions of East, and confiscation of this book served as a catalyst to it, hence the young writers, besides romanticism, started to think about the issues of life. ${ }^{13}$

The fiction stories were included in Angaray when reviewed from a conceptual and artistic point of view, keeping in sight their contemporary perspective, would bring forth the fact that the authors of Angary made an attempt at their level to defreeze the social rigidity. Besides making an effort to introduce Urdu fiction in a realistic style they also set such example of artistic boldness which gave a new dimension to Urdu fiction, but it changed the entire scenario of the fiction literature. According to Dr. Aziz Fatima:

When we see these fiction stories, we tend to believe that colors of real life, its ups and downs and different shades like success, happiness, failure, hardships, beliefs, traditions and norms, desires and fantasies the depiction of which was founded in 1920 to 1929 , it became an essential part of arts during the next five years. $^{14}$

12 Waqar Azeem, Dastaan se Afsanay tak, (Delhi: Tahir Book Agency, 1972), p.262.

${ }^{13}$ Dr. Anwar Sadeed, Urdu Adab ki Tehreekain, (Karachi: Anjuman Taraqqi-e-Urdu, 2013), p.436.

${ }^{14}$ Dr. Aziz Fatima, Urdu Afsana, Samaji-o-Saqafati Pasmanzar, (Lucknow: Nusrat Publishers, 1984), p.121. 
Therefore, if literature is linked with ground realities, and if it is an evidence of consciousness to acquire the knowledge of the changes in life and prepare the society for the consequences and events of future, then in Angaray one can realize the solution of these social issues. The fact, here, needs to be kept in view that writings in the literature become effective only through their indirect expression of particular objectives. Angaray remains unfortunate in that most of its critics contain themselves to the extent that they either condemn or commend it. The opponents of the said collection declared it a piece of immaturity in sense of religion and gender, extremism and even a collection of indecent words, for example, Dr. Ibadat Barelvi at a point notes down:

The stories of Angaray contain extremism. Some of these do not even match the standards of arts, while on several occasions satire turns into deep obscenity and disgust. At several places disruptive trends also appear to emerge and at others one will find the childlike ticklish sort of characteristic. Yet, despite all these deficiencies, the stories of Angaray are used for the first time to target the social evils. These stories have been the source to clearly reveal the wrong and unequal distribution of wealth and the consequent poverty, difference of classes and its influences, false beliefs about religion and the indifferent values, metaphysical beliefs and superstition, sex hunger and the various psychological complexities caused by it. ${ }^{15}$

While on the other side the supporters of the said collection have admired the bold expression found in these stories. Keeping in view the way efforts were made to promote Urdu fiction by expressing it using the modern Western techniques and contemporary international literary behaviors, no notable attempts were made to look into these or to assess the literary value of the said collection. In this concern, Dr. Sagheer Ifrahim notes that:

Angaray emerged in the light of the western arts and conceptual theories. Its authors realized the fact quite well that country issues could not be solved merely by ideas about reform, rather a practical attitude was needed for this purpose. The very act of extremism emerged in the form of Angaray. The writers of this collection had chosen the contemporary society and its terrible mentality as the theme of this fiction work. They had pointed to the ugly face hidden behind the veil. ${ }^{16}$

After 1932, Angaray technically placed great influence on the later fiction writers. That is why we observe that after publication of Angaray, Prem Chand opted revolutionary approach instead of reformative view. After that we see another prominent fiction writer Krishan Chandar who was also influenced by the air of Angaray but this influence remained for a short period. Next, we observe another fiction writer Saadat Hasan Manto to have come under influence of the communist movement and ideology. When Manto entered the field of fiction along with his straight-forward factual writing, humanity, mature character writing skill and deep consciousness of human psychology, he was also impressed by the scenario created around by Angaray. However, Manto by technique was a perfect fiction writer, and for this reason we can easily determine the maturity of fiction skills in his work. Following that there was another fiction writer

15 Dr. Ibadat Barelvi, Tanqeedi Tajrubay, Urdu Dunya, (Karachi, 1959), p. 320.

16 Dr. Qamar Raees, Tanqeedi Tanazar, (Aligarh: Educational Book House, 1967), p.81. 
Asmat Chughtai who appears impressed by Angaray. She is also blamed for obscene writings. Her stories openly describe the sexually frustrated women and men. Angaray, it can be claimed, served as the source of courage and support to the fiction writers who were to follow. However, the increase we observe in the fiction literary seems to be so much mature in terms of technique that lacked in Angaray. This deficiency is recognized by most of the critics. In this concern, Aziz Ahmed writes:

The most significant defect in Angaray was the lack of cautiousness and the extreme favor for indiscipline. For that cause this book met its disruptive purpose but it could do nothing constructive. No doubt it is backwardness to manipulate religion for the sake of capitalism, but irrational attacks on religion are not declared fair even by the communist mind. ${ }^{17}$

While making an analysis of the influence of Angaray on Urdu fiction, it needs to be kept in view that although Angaray bears a historic status in present times but at the same time this collection is the starting point of progressive fiction writing and an important turn of the Urdu fiction history, and this turn leads Urdu fiction into a broader world. In the words of Dr. Qamar Raees:

It won't be out of place to say that the very publication of Angaray was a call for the progressive writers' movement and the first informal announcement of this movement. Its rebellion carried the message of rise of a new revolutionary contemplation against the obsolete beliefs, outmoded institutions, anti-social forces and the ignorant social and moral laws. ${ }^{18}$

\section{Conclusions}

Reviewing of the literature gives us to conclude that the fiction stories compiled in the form of Angaray were an attempt to highlight social issues. Since the bold expression prevailing at the time of publication of Angaray did not match the values of the society as well as the expectations of the readers (who would consider such boldness as obscenity), these created a fuss among the literary circles. But it is also evident that Angaray beginning of short stories with modern approach.

However, in the present time, when the communication means have enhanced access of everyone to a lot of literature disregarding the values or otherwise of the society, the mode of expression used by the writers of Angaray appears acceptable and a sign of courage at a time when it was really difficult to raise one's voice in such a way. This however reminds all the writers that it is their duty to keep developing awareness among the people about their social issues in decent but clear ways. Freedom of expression and highlighting the social issues in sophisticated manner is much more important which could not contradict to the socio-cultural values and religious norms.

${ }^{17}$ Prof. Sagheer Ifrahim, Urdu Afsana, Traqqi Pasand Tehreek se Qabl, (Aligarh: Educational Book House, 2009), p.210.

${ }^{18}$ Aziz Ahmed, Traqqi Pasan Adab, (Hyderabad Dakkan: Idara Isha'at-e-Urdu, 1945). 